\title{
PREPOSITIVE ADJECTIVE IN RUSSIAN PROVERBS AS A MEANS OF EXPRESSING CAUSAL RELATIONS ${ }^{1}$
}

\author{
Svetlana L. Mikheeva \\ I.Ya. Yakovlev Chuvash State Pedagogical University, Cheboksary, Russia
}

\begin{abstract}
The article deals with Russian proverbs that include a nominal phrase with an adjective as an attributive modifier. The material for the study was proverbial expressions which were compiled from V. I. Dal's collection of Russian proverbs (378 units). The subject of the analysis is prepositive adjectives involved in the formation of cause-effect semantic relations in expressions such as Dobryi kon' borozdy ne isportit (A good horse will not spoil furrow), Staryi drug luchshe novykh dvukh (The old friend is better than the new two ones). The syntactic functions of the adjectives are considered by means of analysis of three thematic groups of proverbs: proverbs showing natural signs, proverbs characterizing a person, proverbs describing a situation. The following regularities affecting the ability of the adjective to realize causal relations in the statements are established: an adjective is included into a semantic part of a nominal phrase (an absolute first position in a sentence); contextual support in the form of a complex of morphological and syntactic means (conjunction-particle $u$, a comparative form of a nominal predicate, syntactic structures based on comparison); evaluative part of statements (correlation with the idea of positive or negative in presupposition). Finally a syntactic function of an adjective is characterized as a means of creating causal determination of the statement. These premises are linked to linguistic embodiment of causal attribution as a specific characteristic of a person who is referred to the system of values of national culture.

Key words: proverb, adjective, causality, causal links, assessment, statement, sentence.

Citation. Mikheeva S.L. Prepositive Adjective in Russian Proverbs as a Means of Expressing Causal Relations. Vestnik Volgogradskogo gosudarstvennogo universiteta. Seriya 2. Yazykoznanie [Science Journal of Volgograd State University. Linguistics], 2019, vol. 18, no. 2, pp. 83-93. (in Russian). DOI: https://doi.org/ 10.15688/jvolsu2.2019.2.8
\end{abstract}

УДК 811.161.1:398.9

Дата поступления статьи: 27.08.2018

ББК $81.411 .2-5$

Дата принятия статьи: 28.03.2019

\section{ПРЕПОЗИТИВНОЕ ПРИЛАГАТЕЛЬНОЕ В РУССКИХ ПОСЛОВИЦАХ КАК СРЕДСТВО ВЫРАЖЕНИЯ КАУЗАЛЬНЫХ ОТНОШЕНИЙ ${ }^{1}$}

\author{
Светлана Львовна Михеева \\ Чувашский государственный педагогический университет им. И.Я. Яковлева, г. Чебоксары, Россия
}

\begin{abstract}
Аннотация. Статья посвящена русским пословицам, в состав которых входят адъективно-субстантивные сочетания. Материалом для исследования послужили пословичные выражения, отобранные методом сплошной выборки из сборника русских пословиц В.И. Даля (378 единиц). Объектом анализа являются препозитивные прилагательные, участвующие в формировании причинно-следственных смысловых от○ ношений в выражениях типа Добрый конь борозды не испортит, Старый друг лучше новых двух. Функционирование прилагательных рассматривается на примере трех тематических групп пословиц: пословицы-приметы; пословицы, характеризующие человека; пословицы, характеризующие ситуацию. Установлены следующие закономерности, влияющие на способность прилагательного реализовать каузальные отношения в высказывании: вхождение адъектива в состав тематической части высказывания (позиция в абсолютном начале предложения); контекстуальная поддержка в виде комплекса морфолого-синтаксических средств (союз-частица $u$, компаративная форма именного сказуемого, синтаксические структуры, (2) выражающие сравнение); оценочный характер высказываний (соотнесение с представлением о положи-
\end{abstract}


тельном и отрицательном). Итогом исследования является вывод об особой роли имени прилагательного как средства создания каузальной детерминации высказывания. Пословицы рассматриваемого типа представляют собой языковое воплощение каузальной атрибуции как специфического свойства человека носителя системы ценностей национальной культуры.

Ключевые слова: пословица, прилагательное, обусловленность, каузальные отношения, оценка, высказывание, предложение.

Цитирование. Михеева С. Л. Препозитивное прилагательное в русских пословицах как средство выражения каузальных отношений // Вестник Волгоградского государственного университета. Серия 2, Языкознание. - 2019. - Т. 18, № 2. - С. 83-93. - DOI: https://doi.org/10.15688/jvolsu2.2019.2.8

\section{Введение}

Модель мира создается человеком на основе установления взаимосвязей между событиями. Она, как отмечает Ю.С. Степанов, «характеризуется учетом всеобщей связи, “системности” в противопоставление "атомизму”» [Степанов, 1985, с. 130]. Каузальные связи и отношения - базовые связи и отношения, на которых строятся представления человека об устройстве мира. Естественное свойство языка поэтому видится в способности (и предназначенности) его единиц выражать эти отношения (как явным, так и неявным способом).

Объектом анализа в настоящей работе являются пословичные выражения, в состав которых входят препозитивные адъективносубстантивные сочетания. Эти сочетания представляют интерес с точки зрения их способности устанавливать причинно-следственные отношения в простом предложении в отсутствие специализированных средств реализации каузальных связей и отношений типа союзов со значением причины и следствия, предложно-падежных сочетаний или наречий с соответствующей семантикой (подробнее о средствах выражения обусловленности в русском языке см.: [Всеволодова, Ященко, 2015; Евтюхин, 1996, с. 153; Оркина, 2010; Соколова, 2018]).

Паремиологические выражения становятся одним из средств категоризации знаний человека о мире и являются подтверждением сформулированного Е.С. Кубряковой тезиса о том, что «категоризация мира - это результат когнитивной деятельности человека, итог классификации (таксономии) окружающего его мира отдельных единиц (таксонов) в произведенной классификации, когда конечным итогом указанной деятельности оказы- вается формирование особой категории, позволяющей увидеть мир в главных атрибутах его бытия и функционирования» [Кубрякова, 2004, с. 64-65]. Пословицы как реализация типовых структурно-семантических моделей предложения представляют собой воплощение так называемых «синтаксических концептов». Как показано в работе Г.А. Волохиной и 3.Д. Поповой, «установление предикативного отношения между мыслительными сущностями (концептами разного рода) - естественный механизм человеческого мышления <...> в состав предикативного отношения входит и типовая пропозиция (категориально-семантический концепт, смысл), для которой и создается структурная схема простого предложения» [Волохина, Попова, 1999, с. 7]. В пословицах, которые стали объектом анализа, предикативные отношения осложнены отношениями обусловленности. В связи с этим наше исследование ориентировано на описание семантики пословицы, построенной по определенной модели предложения в аспекте, связанном с неспецифическим средством выражения причинно-следственной обусловленности - именем прилагательным (подробнее о способности прилагательного к выражению отношений обусловленности в художественном дискурсе см.: [Михеева, 2015]).

\section{Исходные положения}

Мир, зафиксированный в пословичных выражениях, представляет собой некую Вселенную, «сотворенную в слове реальность». В этой реальности действует свод законов, словесным воплощением которых являются пословицы. С одной стороны, они предписывают способ поведения в зависимости от ситуации - имеют прескриптивный характер $(\mathrm{He}$ в свои сани не садись; На Бога надейся, а 
сам не плошай; Не плюй в колодец: пригодится и воды напиться; Береги платье снову, а честь смолоду и т. п.). Прескрипция находит прямое выражение в форме повелительного наклонения глагольного слова. С другой стороны, в паремиях максимально обобщен итог многократно повторяющейся ситуации: каждый индивидуальный эпизод, в рамках которого происходит череда закономерных и предсказуемых событий, - это частный случай типовой ситуации. Причем, отметим это особо, само пословичное выражение имеет двойное смысловое наполнение. Во-первых, оно оказывается, еще раз повторим, обобщением закономерности, выводимой из наблюдений за многократно повторяющимися ситуациями, разворачивающимися по одному и тому же сценарию и имеющими один и тот же финал. В этом случае пословица становится средством категоризации знаний о мире: все многообразие явлений, событий, человеческих поступков может быть сведено к той или иной формуле (Без труда не выловишь $и$ рыбки из пруда; Терпение и труд все перетрут; Хлеб - всему голова; На чужой роток не накинешь платок; Рыба ищет, где глубже, а человек - где лучше и т. п.). Вовторых, сама пословица, уже сформировавшись, выступает неким указателем, «ярлыком», под который подводится любая новая ситуация, если по своим признакам, характеру протекания она соответствует заложенным в пословице параметрам. Этот аспект находит отражение в словарях пословиц и поговорок, где представлен комментарий - толкование значений выражений, часто с указанием на то, в какой ситуации они употребляются.

Особого внимания в массиве паремий русского языка заслуживают пословицы, построенные по модели: $\operatorname{AdjN}_{1} \mathrm{Vf} / \operatorname{AdjN}_{1} \operatorname{Comp~}_{2}$ : Кроткое слово гнев побеждает; Ласковое слово лучше мягкого пирога и т. п. Оговорим сразу несколько моментов. Приведенные модели - частные случаи, иллюстрирующие более общую типовую структуру, в которой значимым с точки зрения настоящего анализа является наличие в препозиции к существительному имени прилагательного. Ограничимся также случаями, где сочетание «прилагательное + существительное» является группой подлежащего, то есть его компоненты употреблены в именительном падеже. В коммуникативной структуре высказывания такая группа занимает позицию темы. Итак, речь идет о пословичных выражениях типа $\boldsymbol{C m a -}$ рый / добрый конь борозды не испортит / мимо не ступит; Незваный гость хуже татарина; Родная сторона - мать, чужая - мачеха; Родимое пятнышко - к счастью и т. п. При такой структурно-семантической организации предложения в нем реализуются отношения причинно-следственной обусловленности. Иными словами, смысловые отношения между тематической и рематической частями высказывания, построенного по модели, о которой идет речь, - это отношения между причиной (тема) и следствием (рема). Порядок слов в этих случаях получает дополнительную смысловую нагрузку.

Материалом для анализа послужили пословицы и поговорки (378 единиц), извлеченные в результате сплошной выборки из словаря В.И. Даля (Даль, 2009).

\section{Тематические группы пословиц}

С точки зрения «явности», выраженности причинно-следственных смысловых отношений и области их проявления, пословичные выражения могут быть обобщены в тематические группы, которые подробно рассматриваются далее.

1. Природные приметы - выражения, в которых, по словам Т.С. Садовой, фиксируются результаты наблюдений за явлениями природы, когда обнаруживается закономерная, предсказуемая на основе многократной или постоянной повторяемости взаимозависимость между этими явлениями [Садова, 2012]. Взаимозависимость реализуется на основе временно́й последовательности (что лежит в основе отношений между причиной и следствием), когда второе невозможно без первого или появление / проявление первого обязательно влечет за собой второе. Приметы фиксируются на основе, как уже было сказано, непосредственных наблюдений. Касаются они погоды, прогнозов об урожайности в общем или какого-либо определенного растения. В эту группу нами отнесены и суеверия.

Прилагательные в таких выражениях акцентируют внимание на гипертрофирован- 
ном признаке предмета, ситуации, проявление которого предвещает то или иное развитие события: Густая опока (иней) - к урожаю овса; Длинные капельники (сосульки) - долгий лен; Сильная завязь орехов - к урожаю проса; Рясная малина - урожай на хлеб; Холодная зима - благодать (предвещает урожсай). Важны не просто иней, сосульки, орехи, малина или зима сами по себе, а именно их особые качества.

Следует отметить, что в синтаксических конструкциях подобного типа на первый план выступают условно-следственные отношения, что находит подтверждение в достаточно простой и однозначной их трансформации в сложноподчиненные предложения с придаточными условия, ср.: Если сильная завязь орехов, то [это] к урожаю проса. Данный факт является дополнительным доказательством того, что смысловые отношения в таких случаях основываются на отношениях причины и следствия и составляют первооснову других мотивационных отношений в высказывании - целевых, уступительных и т. д. Так или иначе, эти отношения могут быть объяснены, истолкованы через семантику причинно-следственной обусловленности. Возвращаясь к выражению условно-следственной связи, добавим еще одно замечание. $Y_{c}$ ловие в значении «обстоятельство, от которого что-либо зависит» семантически близко слову причина в значении «явление, вызывающее, обусловливающее возникновение другого явления» (Ожегов, Шведова, 1997). Различия между условием и причиной, видимо, следует усматривать в степени обязательности проявления следствия - для причины это более жесткая связь.

В связи с этим взаимозависимость двух ситуаций, которые в составе приметы соотносятся как причина / условие и следствие, устанавливается на основе непосредственного наблюдения за природными явлениями, жизнью и поведением растений и животных. Это то, что возможно проверить эмпирическим путем. В подобных выражениях прилагательные реализуют свои прямые значения, сами пословицы-приметы понимаются в буквальном смысле.

Особое место среди примет занимают приметы-суеверия. В этой статье не ставит- ся задача подробного анализа таких выражений, поэтому ограничимся несколькими замечаниями, которые имеют отношение к рассматриваемой теме. В приметах-суевериях для прилагательного открывается возможность развить или реализовать символическое значение. Суеверия по своему происхождению восходят к мифологическим представлениям об устройстве мира. С этим связано предопределение тех отношений мотивации, которые обнаруживают себя в соответствующих выражениях пословичного типа: Родимое пятнышко - к счастью; Краденые семена лучше рождаются; Рыжий да красный - человек опасный; Срослые брови сулят счастье; Черные тараканы заводятся $\kappa$ прибыли; Сухое бревно в срубе - к счастью; Черная и пестрая корова впереди стада - к ненастью, белая и рыжая $\kappa$ ведру. В подобных выражениях отражены архетипические установки, сопровождающие человека с древнейших времен. Особенно ярко эти установки проявляются в отношении цветовых прилагательных. Например, с одной стороны, рыжий, красный - цвет, устойчиво ассоциируемый с солнцем и огнем (рыжая корова впереди стада - это символ хорошей, солнечной погоды), в противоположность черному - цвету темного, ненастного дня; с другой - рыжий да красный опасны, как могут быть опасны огонь или солнце в дни палящего зноя и засухи.

Истоки каузативного смысла у прилагательных, входящих в тематическую часть в предложении-пословице со значением приметы-суеверия, необходимо восстанавливать с опорой на мифологию и фольклор, с учетом символического оттенка в значении прилагательного. Все это требует отдельного, тщательного рассмотрения.

2. Пословицы, характеризующие человека.

Данную тематическую группу можно определить на основе паремиологических выражений, которые характеризуют человека с какой-либо стороны:Добрый человек надежнее каменного моста; Добрый человек добру и учит; Злой человек не проживет в добре век и т. п.

Принцип построения выражения и, соответственно, принцип соотнесения каузативно- 
го признака-свойства с его следствием - другим признаком-свойством или характерным действием - таков же, как и в выраженияхприметах. Фиксируется типическое, предсказуемое, или прогнозируемое, поведение. При этом априори предполагается, что в коммуникации говорящий и адресат понимают, осознают семантический объем прилагательного, находящегося в препозиции, в абсолютном начале выражения, и именно это позволяет предвидеть, предугадать развитие ситуации. Иными словами, необходимо изначально знать, что значит быть хорошим, добрым или плохим, злым и т. п., чтобы установить причинно-следственную связь, закономерность в поведении человека или выразить дополнительную оценку к его исходному качеству: Незваный гость хуже татарина; Затейливые ребята недолговечны; Хороший гость хозяину в почет; Близкий сосед лучше дальней родни; Старый друг лучше новыx двух и т. п. С одной стороны, в высказывании это априорное знание закономерно оказывается в позиции темы, то есть в части, которая содержит исходный, известный фрагмент информации; с другой - оно не появляется как данность само по себе, это итог и обобщение многочисленных наблюдений за закономерностями в поведении человека, усвоение и принятие норм и оценок, существующих и действующих в культуре, к которой человек относится. Сами пословицы как некий кодекс нравственно-этических установок народа участвуют в формировании и закреплении в сознании человека шкалы ценностей и ценностного отношения к миру, к самому себе и другим. Прилагательное в таких выражениях приобретает особую функционально-семантическую значимость.

Актуальным в паремиях становится противопоставление и сопоставление, которые строятся на оппозициях, относимых к числу архетипических: хороший (добрый) / плохой (худой), добрый / злой. В самом широком обобщении противопоставление сводится к оценке какого-либо явления как положительного или отрицательного - в соответствии, как уже было сказано, с действующей шкалой оценок. Под это универсальное противопоставление могут быть подведены пары свой / чужсой, сытый / голодный, богатый / бед- ный, званый / незваный и т. п.: Своя рубаха ближе к телу; Своя ноша не тянет; Чужой человек в доме - колокол; Чужой рот не хлев - не затворишь; Чужой ум не попутчик; Сытое брюхо спит, голодное на слуху сидит; Тощиий живот ни в пляску, ни в дело; Незваные гости с пиру долой; Убогий мужик и хлеба не ест, богатый - и мужика crecm.

В пословицах человек часто выступает в какой-либо социально-бытовой роли. При характеристике этих ролей задействуется система эталонов и стереотипов, связанных с типичным, должным поведением человека в какой-либо из своих ипостасей - как мужчины / женщины (соответственно мужа / жены, отца / матери, брата / сестры, сына / дочери и т. п.); как представителя той или иной национальности, социального слоя, профессии или рода занятий: Красивый мужс на грех, а дурной на смех; Скоморохова жсена всегда весела; Честный муж одну только жену обманывает; Умная жена как нищему сума - все сбережет; Сварливая жена в доме пожар; Добрая жена дом сбережет, а плохая рукавом разнесет; Отиовская клятва суиит, а материна коренит; Материнская молитва со дна моря вынимает; Больная жена мужу не мила; Блудный сын - ранняя могила отиу; Меньшой сын на корню сидит; Русский человек без родни не живет; Голодный француз и вороне рад; Казенный крестьянин живет, как бог велит, а барский - как барин рассудит; Добрый раб за господина умереть рад; Завистливый поп два века живет; Добрый портной с запасом шьет; Старый полковник старше молодого генерала; Пьяный солдат по льду перейдет, а собака провалится; Добрый вор без молитвы не украдет; Умный товарищ - половина дороги.

Образную, метафорически осмысленную характеристику человека передают выражения с анималистическим компонентом. Степень употребительности названия того или иного животного в составе пословицы определяется близостью к человеку и значимостью в его жизнедеятельности - это домашние и дикие животные, обитающие в определенной природной зоне, их образы являются фоном для культуры, распространенной в этой 
зоне. В общем паремиологические образы животных оказываются носителями тех или иных качеств и в таком отношении напрямую связаны с фольклорными мотивами и мифологией. Качество приписывается животному как характерный признак на основе повседневных наблюдений за его поведением, повадками, и все это в итоге переносится на человека: Голодный волк сильнее сытой собаки; Лисье племя только льстит да манит; Добрый конь не без седока; Домашний теленок лучше заморской коровы; Живой пес лучше мертвого льва; Мертвый пес зайиа не нагонит; Добрая наседка одним глазом зерно видит, другим глазом коршуна; Сердитый волк в капкане сам себе лапу отъест, а в руки не дастся; Маленькая собачка до старости щенок; Ретивая лошадка недолго живет; Надсажен конь недалеко везет; Блажная собака и на небо лает; Плохое порося и в петровки зябнет; Старый волк знает толк; Добрый (старый) конь борозды не испортит (мимо не ступит); Драчливый петух жирен не бывает; Свиные глазы не боятся грязи и т. п.

Пословицы о человеке становятся средством вербализации системы действующих в той или иной национальной культуре эталонов и стереотипных представлений. Это выраженияформулы, которые категоризуют мир на основе системы ценностей - этических, эстетических, телеологических и др. Наиболее полное воплощение и реализацию процесс категоризации получает в выражениях с субстантивированными прилагательными. Признак, обозначенный субстантивом, абсолютизируется, осмысливается как самостоятельная сущность, которая важна уже вне связи с его носителем, тоже обозначенным существительным. Самостоятельность, самоценность характеризующего признака, качества, свойства находит свое «физическое» воплощение в опредмечивании признакового значения и соответственно в приобретении словом-прилагательным грамматических свойств слова-существительного - фиксации родовой отнесенности, номинализации падежных и числовых форм: Сыmый голодному не товариш; Мертвый с погоста не ворочается; Пьяный проспится, а дурак никогда; Злой плачет от зависти, а добрый от жалости; Горбатый на базаре шубы не по- купает; Мокрый дождя не боится; Запасливый нужды не терпит; Удалой недолго думает; Богатый-то с рублем, а бедный-то со лбом; Скупой запирает крепко, а потчует редко; Тихий наедет, а бойкий сам наскочит; Счастливый на коне, бессчастный пеш; Голый разбою не боится; Злой не верит, что есть добрые люди; Живой не без места, мертвый не без могилы; Смирный в артели - клад.

Наблюдается следующая закономерность процесса субстантивации: в выражениях с формами мужского рода субстантивированный признак однозначно соотносится с представлением о человеке как носителе названного признака; в выражениях с формой среднего рода признак-субстантив не соотнесен с каким-либо конкретным носителем: это максимальное абстрагирование, отвлечение качества как такового - его, как уже было сказано, абсолютизация. Форма среднего рода становится грамматическим средством выражения значения отвлеченности, а такое направление субстантивации - путь пополнения состава отвлеченных существительных: Неправедное как пришло, так и ушло, а праведная денежка век кормит; Казенное на грех наводит; Казенное на воде не тонет, на огне не горит; Зашибенное вспухнет, а посеянное взойдет; Лучшее - враг хорошего.

При субстантивации каузативный оттенок в значении признака-субстантива выходит на первый план. Среди прочих условий протекания данного процесса наличие такого компонента в семантике исходного прилагательного играет если не ведущую, то одну из главных ролей. Необходимо также отметить, что позиция прилагательного в тематической части высказывания позволяет ему реализовать причинно-следственные отношения и субстантивироваться в формах косвенных падежей: Конного гостя провожай до коня, а пешего до ворот; Чужую беду руками разведу, а к своей ума не приложу; На гнилой товар да слепой купец; Повинную голову (покорной головы) и меч не сечет; Доброму человеку - что день, то и праздник; Доброму человеку и чужая болезнь к сердиу; Пьяному море по колено; Богатому завсе праздник; Горбатого исправит могила, а упрямого дубина; Лежачего не бьют; Доб- 
рому бог помогает; Убогому подле богатого жить - либо плакать, либо тужить.

3. Пословицы, характеризующие ситуацию.

Выводы и обобщения, сделанные на основе анализа примет и пословичных выражений, характеризующих человека, оказались справедливыми и закономерными и по отношению к паремиям, в которых описывается какая-либо типичная ситуация, положение дел. Причинно-следственные отношения фиксируются как итоговое обобщение наблюдений за множеством схожих ситуаций - появляются так называемые генерализованные высказывания, вне времени и пространства, с максимально обобщенным субъектом. Пословицыхарактеристики ситуаций вмещают в свое смысловое пространство свойства и пословицпримет (как и приметы, они рождаются на основе эмпирических наблюдений и констатации фактов), и пословиц-характеристик человека (они имеют ярко выраженную оценочность и соотносимы со шкалой ценностных измерений). В фокусе такого выражения находятся разнообразные значимые с точки зрения человека аспекты ситуаций сферы его деятельности: труд, досуг, социально-бытовые взаимоотношения, религия и ритуалы, связанные с ней, отношение к миру природных явлений и т. п.: Старинная пословица не мимо молвится; Добрая земля назем раз путем примет, да девять лет помнит; Красное лето никому не докучно; Царский праздник не наш день, а государев; Чужая изба засидчива; Мартовское пиво с ног сбило; Убогая гордость - дьяволу потеха; Невольная женитьба не веселье; Господская болезнь - крестьянское здоровье; Кривое веретено не исправится; Рогожный парусок лучше крашеных весел; Честное слово $u$ буйну голову смиряет; Добрая слава лежит, а худая бежит; Домашние мысли в дорогу не годятся; Тихая вода берега подмыввает (и плотины рвет); Тупой серп руку режет пуще острого; Первая пороша - не санный путь; Недорубленный лес скоро вырастает; Доброе начало полдела откачало; Трудовая денежка плотно лежит, чужая ребром торчит; Добрый жернов все смелет, плохой сам смелется; Мирская шея жилиста; Семейная каша погуще ки- пит; Золотой молоток и железные двери отворяет; Невеяный хлеб не голод, а посконная рубаха не нагота; Великий пост всем прижмет хвост; Неподмазанное колесо скрыпит; Строгий закон виноватых творит; Царские милости в боярское решето сеются.

Препозитивные прилагательные в такого рода выражениях не только характеризуют объект, но и акцентируют смысловой фокус высказывания на предполагаемых и предвидимых причинно-следственных связях, которые закономерно выявляются в рематической части предложения. Признак, названный прилагательным, обусловливает то или иное развитие ситуации.

Пословицы, обладая особыми этнокультурными и собственно лингвистическими свойствами, отличаются одновременной свернутостью и развернутостью смысла: в минимальной внешней структуре (собственно языковой формуле) реализуется максимально широкий смысл - от повседневного, бытового до широкого философского. Кривое веретено не исправится - не исправится как буквальное веретено, сделанное криво и из-за этого создающее помехи при прядении, так и любой объект, в котором есть дефект, изъян неисправимый и поэтому постоянно мешающий в каком-либо деле. Образ кривого веретена становится символом непригодной для своего прямого назначения вещи, непригодной в силу своей «неправильности», несоответствия эталону - прямому веретену. Весь этот семантический объем (и даже бо́льший) вложен в короткое пословичное выражение. Для его понимания, с одной стороны, нет необходимости в предыдущем или последующем контексте, как это происходит в связном тексте; с другой - требуются достаточно широкие по охвату фоновые, «энциклопедические» знания. Если с этих позиций подходить к оценке роли прилагательного в рассматриваемом типе синтаксических конструкций, по которому построены пословицы, то можно предположить, что роль эта заключается в формировании вида предложений, которые по своей природе служат средством выражения каузальной атрибуции.

Под каузальной атрибуцией в социальной психологии понимается склонность человека 


\section{РАЗВИТИЕ И ФУНКЦИОНИРОВАНИЕ РУССКОГО ЯЗЫКА}

к выяснению и интерпретации причинно-следственных зависимостей в поступках, переживаниях и поведении других людей. Установление и приписывание причин осуществляется во многих случаях на основе сопоставления поведения человека с каким-либо образцом, зафиксированным в прошлом опыте воспринимающего субъекта. Значимым оказывается при этом процессе оценивание поведения как социально желательного, соответствующего социальным и культурным нормам, и социально нежелательного, нарушающего эти нормы [Андреева, 2001, с. 96-98].

Рассматриваемые здесь пословицы с препозитивным прилагательным - это, на наш взгляд, непосредственное воплощение каузальной атрибуции. Их структурно-семантические свойства и коммуникативное назначение позволяют выделить особый функционально-прагматический тип высказываний с каузативной семантикой, где имя прилагательное, являясь второстепенным членом предложения в структурном плане, оказывается его смыслоорганизующим началом с точки зрения выражения причинно-следственной обусловленности. Эти пословицы, как уже отмечено ранее, формируют и фиксируют систему норм и антинорм, действующих в той или иной культуре.

\section{Функции \\ морфолого-синтаксических средств в пословицах с каузальной семантикой}

Оценочная шкала может переосмысливаться. В этом случае в пословице специально оговаривается такой момент, акцент делается на преобразовании положительного в отрицательное и наоборот. Для этого используются специальные средства выражения: препозитивный союз-частица $u$, противопоставительные конструкции с союзами $a$, дa, бессоюзные конструкции с отношениями противопоставления: И худой живот, да хлеб жует; И поджарый (и тонкий) живот без еды не живет; И худой квас лучше хорошей воды; И красное солнышко на всех не угождает; И маленькая рыбка лучше большого таракана; Черны руки, да бела копеечка; Черна корова, да бело молочко; Невеличка птич$\kappa a$, да ноготок остер; Невеличка блошка, a спать не дает; Чужая земля - лебедуш-

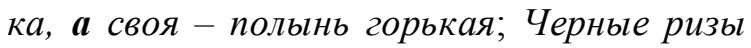
не спасут, а белье не погубят; Рабочий конь на соломе, а пустопляс на овсе; Мальй вор бежит, большой лежит.

Одно из специализированных средств выражения переосмысления оценки, перенесения ее с одного полюса на другой - это конструкции типа $\mathrm{N}_{1}$ лучше / хуже $\mathrm{N}_{2}$, в которых сопровождающие прилагательные противопоставлены антонимически: Худой мир лучше доброй брани (драки, ссоры); Соломенный мир лучше жселезной драки; Худое молчание лучше доброго ворчания; Сытый волк смирнее завистливого человека; Умная ложь лучше глупой правды; Цыганская правда хуже православной кривды; Скупой богач беднее нищего; Городское теля мудреней деревенского пономаря; Духовное родство пуще плотского; Живое слово дороже мертвой буквы; Худое ремесло лучше хорошего воровства; Маленькая добычка лучше большого наклада; Домашняя гривна лучше заезжего рубля; Медные деньги звонче золотых. При таком противопоставлении либо положительную оценку получает признак, который в обычной ситуации соотносится с отрицательным полюсом, поэтому становится возможным, что нечто «худое» оказывается лучше и предпочтительней чего-либо «хорошего», «доброго», а медные деньги ценятся дороже золотых, либо положительная или отрицательная оценка подтверждается, усиливается - в тех случаях, когда противопоставление, противоречие возникает внутри словосочетания «прилагательное + существительное»; при этом формируется сложная, многокомпонентная оппозиция оценок, ср.: сытылй волк-завистливый человек; умная ложь - глупая правда; цүыганская правда - православная крив$\partial a$ (в основе многих подобных выражений лежит оксюморонное сочетание).

Возвращаясь к лингвистической стороне рассматриваемого типа пословиц, отметим их значимые особенности. Если говорить о паремиях, построенных по модели простого предложения, можно выделить их структурные типы в зависимости от способа выражения предиката. Первый тип - это предложения с глагольным предикатом (типа Старая пословица век не сломится; Мартовское 
пиво с ног сбило; Волчья шкура и в городе воет; Хороший товар сам себя хвалит); второй - с именным предикатом. Последний подразделяется на подтипы в зависимости от конкретного средства выражения именного сказуемого: предложения с предикатом-существительным (Золотая клетка соловью не потеха; Плохая шутка баламутка; Хороший лов рыбы - к урожаю хлеба); с прилагательным в краткой форме (Чужая изба засидчива; Званый гость убыточен; Хвастливое слово гнило); с прилагательным в форме сравнительной степени (Нежданныц гость лучше жданных двух; Почтенный покупатель дороже денег; Даровое льчко лучше купленного ремешка).

Паремии, построенные по модели сложного предложения, также можно классифицировать и на других принципах - на основе смысловых отношений между частями и по характеру средств связи между ними. Предложения союзного типа - это, как правило, построенные на основе антитезы сложноподчиненные предложения с сопоставительно-противительным союзом а: Добрая слава за печкой сидит, а худая по свету бежит; Чужсй дурак - веселье, а свое - бесчестье. Им синонимичны бессоюзные конструкции сопоставительного характера: Хорошая жизнь ум рождает, плохая и последний теряет; Тесный сапог разносится, широкий ссядется; Добрая земля - полная мошна, худая земля пустая мошна. Кроме того, среди бессоюзных конструкций выделяется тип с ярко выраженными условно-следственными смысловыми отношениями: Западный ветер под низкими облаками - пора сеять ярииу; Крылатые муравьи показались - сей овес; Длинные капельники (сосульки) - долгий лен; Рясная малина - урожай на хлеб. Здесь препозитивное прилагательное - ключевое средство, смысловой центр, благодаря которому устанавливаются отношения условия / причины и следствия: важен не любой ветер, а именно западный; важны не муравьи вообще, а именно крылатые.

\section{Выводы}

В результате проведенного исследования охарактеризовано функционирование препози- тивного прилагательного в составе пословиц русского языка. Выявленные особенности его использования позволяют по-новому осмыслить семантическую природу этой части речи и ее функциональный потенциал. В отводимой прилагательному достаточно скромной роли второстепенного члена предложения (определения) заключена более глубокая смысловая идея: эти слова, называя тот или иной признак, соотносимый с предметом, явлением и привязанный к ним, создают и поддерживают в предложении каузальную детерминацию, в которой реализуется назначение имени прилагательного. Такие соображения ведут далее к мысли о необходимости расширения перечня средств выражения каузативности, среди которых традиционно оказываются глаголы, добавлением в него имени прилагательного. Остается открытым вопрос, возможно ли говорить о том, что любое прилагательное способно реализовать каузативное значение. Ответ на него требует тщательного исследования.

Одна из обнаруженных в результате анализа закономерностей заключается в том, что каузативное значение у прилагательного в полной мере проявляется при включении атрибутива в группу подлежащего, которая находится в абсолютном начале высказывания. В этой позиции каузативность реализуется у адъектива и в именительном, и в косвенных падежах.

Следует попутно отметить, что это наблюдается не только в русском предложении. Можно предположить, что такие свойства атрибутивов реализуются и во многих других индоевропейских языках. Верификация этой гипотезы составляет перспективы исследования.

\section{ПРИМЕЧАНИЕ}

${ }^{1}$ Работа выполнена в рамках государственного задания Министерства образования и науки Российской Федерации (проект № 27.9712.2017/БЧ «Полиэтническая образовательная среда современного вуза: проблемы многоязычия и межкультурной коммуникации»).

The work was carried out in the framework of the state task of the Ministry of Science and Higher Education of the Russian Federation (project no. 27.9712.2017/БЧ "Polyethnic Educational Environment of a Modern University: Problems of Multilingualism and Intercultural Communication"). 


\section{СПИСОК ЛИТЕРАТУРЫ}

Андреева Г. М., 2001. Социальная психология. М. : Аспект Пресс. 290 с.

Волохина Г. А., Попова З. Д., 1999. Синтаксические концепты русского предложения. Воронеж : ВГУ. 196 с.

Всеволодова М. В., Ященко Т. А., 2015. Причинноследственные отношения в современном русском языке. М. : ЛИБРОКОМ. 210 с.

Евтюхин В. Б., 1996. Группировка полей обусловленности: причина, условие, цель, следствие, уступка // Теория функциональной грамматики. Локативность. Бытийность. Посессивность. Обусловленность. СПб. : Наука. С. 138-174.

Кубрякова Е. С., 2004. Язык и знание: На пути получения знаний о языке: Части речи с когнитивной точки зрения. Роль языка в познании мира. М. : Языки славянской культуры. 560 с.

Михеева С. Л., 2015. Признак, обусловливающий действие: о роли прилагательного в высказывании при выражении причинных отношений // Научный диалог. № 12 (48). С. 120-131.

Оркина Л. Н., 2010. Синтаксические структуры с семантикой обусловленности в современном русском языке. СПб. : САГА. 332 с.

Садова Т. С., 2012. Народная примета о традиционных ценностях // Русский язык в школе. № 3. C. $78-81$.

Соколова Е. В., 2018. Специфика выражения отношений обусловленности в русских пословицах // Научно-методический электронный журнал «Концепт». № 2. С. 161-167.

Степанов Ю. С., 1985. В трехмерном пространстве языка: Семиотические проблемы лингвистики, философии, искусства. М. : Наука. 335 с.

\section{СЛОВАРИ}

Даль, 2009 - Даль В. И. Пословицы русского народа. М. : Дрофа, 2009. 816 с.

Ожегов, Шведова, 1997 - Ожегов С. И., Шведова Н. Ю. Толковый словарь русского языка. М. : Азбуковник, 1997. 994 с.

\section{REFERENCES}

Andreeva G.M., 2001. Sotsialnaya psikhologiya [Social Psychology]. Moscow, Aspekt Press Publ. 290 p.

Volokhina G.A., Popova Z.D., 1999. Sintaksicheskie kontsepty russkogo predlozheniya [Syntactic Concepts of the Russian Sentence]. Voronezh, VGU. 196 p.
Vsevolodova M.V., Yashchenko T.A., 2015. Prichinnosledstvennye otnosheniya $v$ sovremennom russkom yazyke [Causal Relations in the Modern Russian Language]. Moscow, LIBROKOM Publ. 210 p.

Evtyukhin V.B., 1996. Gruppirovka poleyobuslovlennosti: prichina, uslovie, tsel, sledstvie, ustupka [Grouping of Fields of Causality: Cause, Condition, Purpose, Result, Concession]. Teoriya funktsionalnoy grammatiki. Lokativnost. Bytiynost. Posessivnost. Obuslovlennost [Theory of Functional Grammar. Locativity. Beingness. Possessiveness. Conditionality]. Saint Petersburg, Nauka Publ., pp. 138-174.

Kubryakova E.S., 2004. Yazyk i znanie: Na puti polucheniya znaniy o yazyke: Chasti rechi s kognitivnoy tochki zreniya. Rol yazyka $v$ poznanii mira [Language and Knowledge: Towards Knowledge of Language: Parts of Speech from a Cognitive Point of View. The Role of Language in the World]. Moscow, Yazyki slavyanskoy kultury Publ. 560 p.

Mikheeva S.L., 2015. Priznak, obuslovlivayushchiy deystvie: o roli prilagatelnogo v vyskazyvanii pri vyrazhenii prichinnykh otnosheniy [Feature Determining Action: On Role of Adjective in Utterance when Expressing Casual Links]. Nauchnyy dialog [Scientific Dialogue], no. 12 (48), pp. 120-131.

Orkina L.N., 2010. Sintaksicheskie struktury s semantikoy obuslovlennosti $v$ sovremennom russkom yazyke [Syntactic Structures with Semantics of Conditionality in the Modern Russian Language]. Saint Petersburg, SAGA Publ. 332 p.

Sadova T.S., 2012. Narodnaya primeta o traditsionnykh tsennostyakh [Folk Sign of Traditional Values]. Russkiy yazyk $v$ shkole [Russian Language at School], no. 3, pp. 78-81.

Sokolova E.V., 2018. Spetsifika vyrazheniya otnosheniy obuslovlennosti $\mathrm{v}$ russkikh poslovitsakh [Specific Ways of Expressing Conditioning Relations in Russian Proverbs]. Nauchnometodicheskiy elektronnyy zhurnal «Kontsept», no. 2, pp. 161-167.

Stepanov Yu.S., 1985. V trekhmernom prostranstve yazyka: Semioticheskie problemy lingvistiki, filosofii, iskusstva [In the Three-Dimensional Space of Language: Semiotic Problems of Linguistics, Philosophy, Art]. Moscow, Nauka Publ. 335 p.

\section{DICTIONARIES}

Dal V.I., 2009. Poslovitsy russkogo naroda [Proverbs of the Russian Folk]. Moscow, Drofa Publ. 816 p.

Ozhegov S.I., Shvedova N.Yu., 1997. Tolkovyy slovar russkogo yazyka [Explanatory Dictionary of the Russian Language]. Moscow, Azbukovnik Publ. $994 \mathrm{p}$. 


\section{Information about the Author}

Svetlana L. Mikheeva, Candidate of Sciences (Philology), Associate Professor, Department of Pedagogy and Methodology of Primary Education, I.Ya. Yakovlev Chuvash State Pedagogical University, K. Marks St., 38, 428000 Cheboksary, Russia, mikhsveta@rambler.ru, https://orcid.org/0000-0001-6895-4722

\section{Информация об авторе}

Светлана Львовна Михеева, кандидат филологических наук, доцент, доцент кафедры педагогики и методики начального образования, Чувашский государственный педагогический университет им. И.Я. Яковлева, ул. К. Маркса, 38, 428000 г. Чебоксары, Россия, mikhsveta@rambler.ru, https://orcid.org/0000-0001-6895-4722 